\title{
Mechanisms of Renal Cell Apoptosis Induced by Cyclosporine A: A Systematic Review of in vitro Studies
}

\author{
Zheng Xiao ${ }^{a}$ Chengwen $\mathrm{Li}^{\mathrm{a}}$ Juan Shan ${ }^{\mathrm{a}}$ Lei Luo ${ }^{\mathrm{a}}$ Li Feng $^{\mathrm{a}} \quad$ Jun $\mathrm{Lu}^{\mathrm{a}}$ \\ Shengfu Li ${ }^{\mathrm{a}}$ Dan Long ${ }^{\mathrm{a}}$ Youping $\mathrm{Li}^{\mathrm{a}, \mathrm{b}}$
}

${ }^{a}$ Key Laboratory of Transplant Engineering and Immunology of the Health Ministry of China, West China Hospital, Sichuan University, and ${ }^{\mathrm{b}}$ Chinese Evidence-Based Medicine Centre, Chengdu, PR China

\section{Key Words}

Cyclosporine A - Apoptotic mechanisms • Renal cells •

Chronic cyclosporine A nephrotoxicity

\begin{abstract}
Background: Chronic cyclosporine A (CsA) nephrotoxicity $(\mathrm{CCN})$ is a major cause of chronic renal dysfunction and has no effective clinical interventions yet. Objective: To reveal the mechanisms of renal cell apoptosis in CCN, we analyzed all in vitro studies of such mechanisms. Methods: We collected all in vitro studies about the mechanisms of renal cell apoptosis induced by CsA in Medline (1966 to July 2010), Embase (1980 to July 2010) and ISI (1986 to July 2010), evaluated their quality according to in vitro standards and extracted data following the PICOS principles and synthesized the data. Results: First, CsA could upregulate Fas and Fas- $L$ expression, increase FADD and apoptosis enzymes (caspase-2, $-3,-4,-7,-8,-9$ and -10 ) and downregulate the $\mathrm{BCl}-2$ and $\mathrm{BCl}-$ $x \mathrm{~L}$. Second, CsA could induce oxidative stress and damage the antioxidant defense system. Third, CsA could increase the expression of HERP, GRP78 and CHOP. Fourth, CsA could induce renal cell apoptosis and increase their iNOS and p53 expression in cultured cells. Conclusions: At least four pathways are involved in renal cell apoptosis induced by CsA in
\end{abstract}

different cell species. Caspases might be their final common pathway in vitro. They might all provide potential points for interventions, but these need to be confirmed in vivo.

Copyright $\odot 2011$ S. Karger AG, Basel

\section{Introduction}

All immunosuppressants and surgical techniques have obviously increased the short-term graft survival rate, but not the long-term graft survival rate. Therefore, how to improve the long-term survival rate/life quality of graft and recipient becomes a critical issue. Current strong immunosuppressants can effectively control acute rejection and protect the graft from injury by suppressing the immune cell activation, proliferation differentiation and migration. However, most also have strong toxicity to normal cells that seriously decrease the long-term graft/patient survival rate and their life quality.

Until now, renal transplantation is still the most common therapeutic option for patients with end-stage renal

\section{Z.X. and C.L. contributed equally to this work.}

\section{KARGER}

Fax +4161306 1234 E-Mail karger@karger.ch www.karger.com
(C) 2011 S. Karger AG, Basel

0250-8095/11/0336-0558\$38.00/0

Accessible online at:

www.karger.com/ajn
Prof. Youping Li, Key Laboratory of Transplant Engineering and

Immunology of the Health Ministry of China

West China Hospital, Sichuan University

Chengdu 610041 (PR China)

Tel. +8628 8516 4032, E-Mail yzmy2010@ hotmail.com 
disease. Their short-term results have been excellent, but long-term graft survivals have not improved substantially in recent times. Cyclosporine A (CsA) is widely used for organ transplantation and autoimmune disorders [1, 2], but it was proven that long-term use of CsA could lead to chronic CsA nephrotoxicity (CCN). Also, it became an important cause of chronic renal dysfunction (CRD) that is the most important cause of graft loss [3-8]. Longterm use of CsA could cause CCN through directly injuring renal cells $[9,10]$, activating the renin-angiotensin-aldosterone system (RAS) $[11,12]$ and upregulating the transforming growth factor- $\beta$ (TGF- $\beta$ ) [13-15], etc. All these lead to renal cell apoptosis and finally to CRD. Therefore, renal cell apoptosis might be one of the primary causes in CRD [3]. Up to now, its apoptotic mechanism is not clear, and there are no effective clinical interventions.

To reveal the mechanisms and provide new ideas for prevention, intervention and further studies of CRD, we systematically evaluated the studies for their apoptotic mechanisms and interventions of CsA-induced renal cell apoptosis in vitro and in vivo. Our systematic reviews (SR) involved: (1) mechanisms of renal cell apoptosis induced by CsA in vitro, (2) mechanisms of renal cell apoptosis induced by CsA in animals, and (3) interventions and their mechanisms of renal cell apoptosis in CCN. The mechanisms of renal cell apoptosis induced by CsA in vitro are reported here.

\section{Methods}

\section{Search Strategy}

Two reviewers (Z.X. and C.L.) independently searched potentially relevant articles in the databases of Medline (1966 to July 2010), Embase (1974 to July 2010) and ISI (1986 to July 2010) using the search strategy ((Nephrotoxicity and (Cyclosporine A or CsA or CyA or Cyclosporine)) and Apoptosis) or ((Cyclosporine A or CsA or CyA or Cyclosporine) and (Renal tubular epithelial cell or Renal cells) and Apoptosis). All articles were collected without language restrictions.

\section{Included/Excluded Criteria}

We included all in vitro studies about the mechanisms of renal cell apoptosis induced by CsA (no limitation of research design and language) and excluded the duplicated articles, meeting abstracts and reviews without specific data.

\section{Evaluation Standards}

The quality of all articles was evaluated according to in vitro standards referencing CRH and the EBM Evidence Pyramid [16] defined by ourselves in the following because there is no generally accepted evaluation standard for basic research studies at present.

Mechanisms of Renal Cell Apoptosis

Induced by Cyclosporine A
Evaluation standards for basic research studies in vitro:

\begin{tabular}{ll} 
Grade & In vitro \\
\hline A & Systematic reviews (i.e. meta-analyses) of studies in vitro \\
B & With comparable baseline \\
C & Baseline unknown \\
D & No comparable baseline
\end{tabular}

Selection and Evaluation of Articles

Two reviewers (Z.X. and C.L.) independently selected and evaluated articles according to in vitro standards defined by ourselves. Any disagreements were resolved by discussion with each other or with Y. Li.

\section{Data Extraction and Synthesis}

All included studies were in vitro studies. They were classified into two groups as characteristics and mechanisms of renal cell apoptosis. Because of poor homogeneity, we synthesized the data by descriptive methods. After reviewing all articles, we designed data extraction tables according to research themes and extracted the experimental data following PICOS, which are cells (P), Interventions (I), Control study (C), Outcomes (O) and Study Design (S) of studies and then synthesized the data.

\section{Results}

\section{Search Results}

Overall, 454 potential articles were identified. On the initial screen, 97 full-text articles were retrieved and assessed for eligibility (fig. 1). Finally, 19 studies met the inclusion criteria.

\section{Quality of Studies}

All 19 in vitro studies had a comparable baseline and we evaluated them as grade $\mathrm{B}$. Their quality grades were shown in data extraction tables.

\section{Main Characteristics of CsA-Induced Renal Cell Apoptosis in vitro}

Twelve experiments on CsA-induced renal cell apoptosis in vitro from 19 articles were included (shown in table 1). Renal tubular epithelial cells (human, pig, canine and mouse), vascular endothelial cell (human and mouse) and human mesangial cells were used in these experiments. The apoptotic rate was detected by the TUNEL method, FITC-annexin binding and DNA fragments, etc. CsA could dramatically induce their apoptosis in a time- and dose-dependent manner when co-cultured with different renal cells. There was no difference of CsAinduced apoptosis in different human renal cell strains. 
Table 1. Main characteristics of CsA-induced renal cell apoptosis in vitro

\begin{tabular}{|c|c|c|c|c|c|c|c|}
\hline \multirow{2}{*}{$\begin{array}{l}\text { Reference } \\
\text { (first author) }^{1}\end{array}$} & \multirow{2}{*}{$\begin{array}{l}\mathrm{P} \\
\text { cells/species }\end{array}$} & \multicolumn{2}{|l|}{ I } & \multirow[t]{2}{*}{$\mathrm{C}$} & \multirow[t]{2}{*}{$\mathrm{O} \uparrow$} & \multirow[t]{2}{*}{$\mathrm{S}$} & \multirow[t]{2}{*}{ QG } \\
\hline & & CsA dose & $\mathrm{T}$ & & & & \\
\hline Esposito [17] & HEC, HK-2 (human) & $800 \mathrm{ng} / \mathrm{ml}$ & $24 \mathrm{~h}$ & & $\sqrt{ }$ & $\sqrt{ }$ & B \\
\hline Amore [18] & cells $^{2}$ (human) & $0.1-1 \mu \mathrm{g} / \mathrm{ml}$ & $4-24 \mathrm{~h}$ & & J & $\sqrt{ }$ & $\mathrm{B}$ \\
\hline Daly [19] & HK-2 (human) & $0.2-80 \mu \mathrm{M}$ & $24 \mathrm{~h}$ & $\sqrt{ }$ & 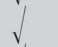 & $\sqrt{ }$ & $\mathrm{B}$ \\
\hline Jo $[20]$ & HK-2 (human) & $1,000 \mathrm{ng} / \mathrm{ml}$ & $24 \mathrm{~h}$ & & $\sqrt{ }$ & $\sqrt{ }$ & $\mathrm{B}$ \\
\hline De Arriba [21] & LLC-PK1 (pig) & $1 \mu \mathrm{M}$ & $24 \mathrm{~h}$ & & $\sqrt{ }$ & $\sqrt{ }$ & $\mathrm{B}$ \\
\hline Perez [22] & PTECs (pig) & $1-1,000 \mathrm{ng} / \mathrm{ml}$ & $48 \mathrm{~h}$ & $\sqrt{ }$ & $\sqrt{ }$ & $\sqrt{ }$ & $\mathrm{B}$ \\
\hline Healy [9] & LLC-PK1 (pig) & $4.2 \mathrm{nM}$ & $24 \mathrm{~h}$ & $\sqrt{ }$ & $\sqrt{ }$ & $\sqrt{ }$ & $\mathrm{B}$ \\
\hline Jeon [23] & MDCK (canine) & $10 \mu \mathrm{M}$ & $48 \mathrm{~h}$ & $\sqrt{ }$ & $\sqrt{ }$ & $\sqrt{ }$ & $\mathrm{B}$ \\
\hline Cheng [24] & MDCK (canine) & $20 \mu \mathrm{M}$ & $24 \mathrm{~h}$ & $\sqrt{ }$ & $\sqrt{ }$ & $\sqrt{ }$ & $\mathrm{B}$ \\
\hline Justo [25] & MCT (mice) & $10 \mu \mathrm{g} / \mathrm{ml}$ & $24 \mathrm{~h}$ & $\sqrt{ }$ & $\sqrt{ }$ & $\sqrt{ }$ & B \\
\hline Conti [26] & EC (mice) & $0.25-2 \mu \mathrm{g} / \mathrm{ml}$ & $12 \mathrm{~h}$ & $\sqrt{ }$ & J & $\sqrt{ }$ & B \\
\hline Ortiz [27] & MCT (mice) & $0.1-15 \mu \mathrm{g} / \mathrm{ml}$ & $24-72 \mathrm{~h}$ & $\sqrt{ }$ & $\sqrt{ }$ & $\sqrt{ }$ & B \\
\hline
\end{tabular}

Cells (P): Proximal tubule epithelial cells (human, pig, canine and mice), vascular endothelial cells (human and mice), human mesangial cells; Interventions (I): CsA (different doses); Time (T): co-cultured times; Control (C): normal culture medium; Outcomes (O):

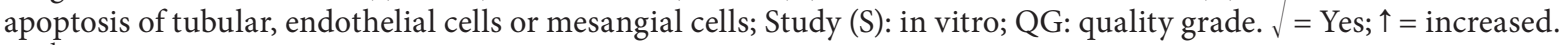

${ }^{1}$ Citation of included articles; different shading shows different cells.

${ }^{2}$ Human mesangial cells, human tubular cells, human umbilical vein endothelial cells, or murine endothelial cells; human endothelial cells (HECs); human renal tubular epithelial cells (HK-2); porcine renal endothelial cell line LLC-PK1; primary cultures of pig kidney proximal tubule epithelial cells (PTECs); Madin-Darby canine kidney (MDCK) tubular epithelial cells; murine proximal tubular epithelial MCT cells; murine endothelial cell line (EC).

Fig. 1. Articles retrieved and assessed for eligibility.

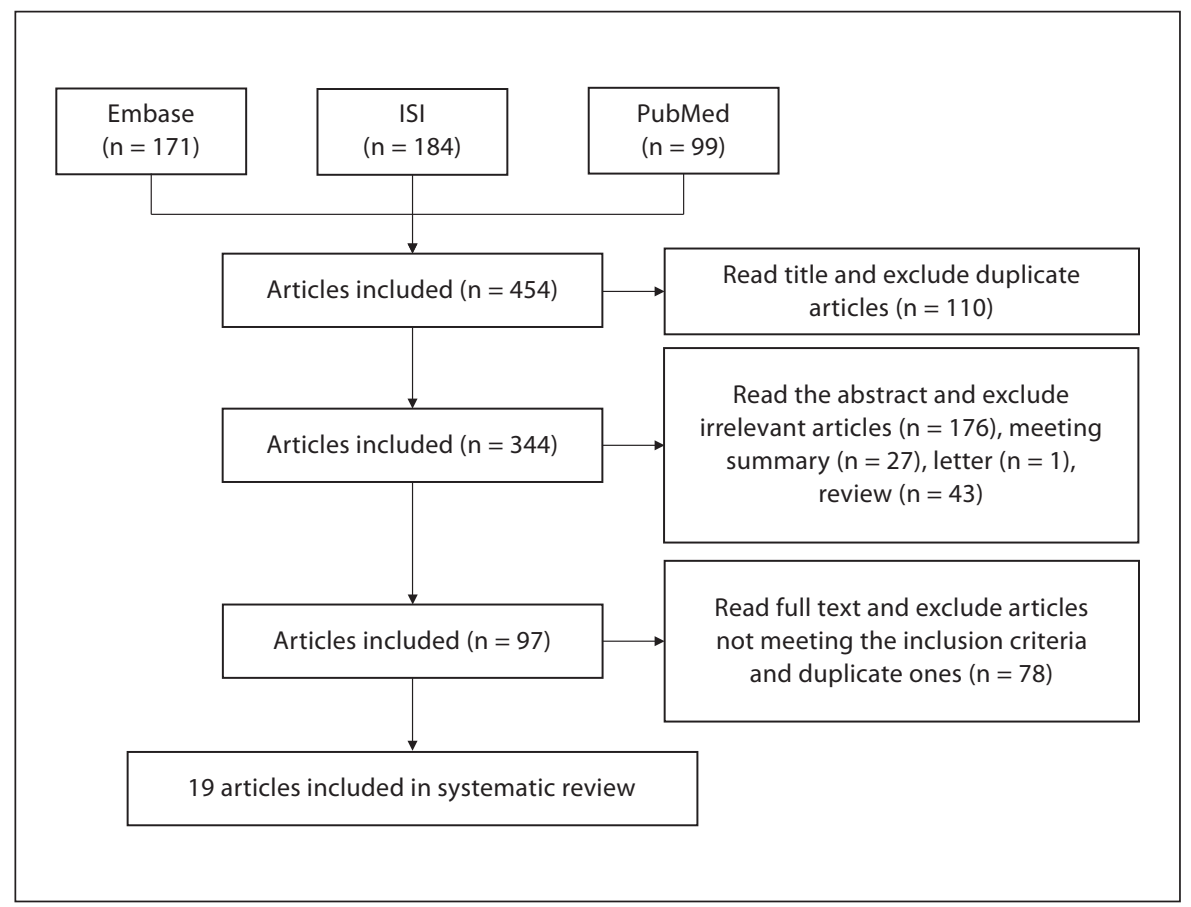


Table 2. Fas/Fas-L pathway

\begin{tabular}{|c|c|c|c|c|c|c|c|c|c|c|}
\hline \multirow{2}{*}{$\begin{array}{l}\text { Reference } \\
\text { (first author) }^{1}\end{array}$} & \multirow{2}{*}{$\begin{array}{l}\mathrm{P} \\
\text { cells }\end{array}$} & \multicolumn{2}{|l|}{ I } & \multirow[t]{2}{*}{$\mathrm{C}$} & \multicolumn{4}{|l|}{$\mathrm{O}$} & \multirow[t]{2}{*}{ S } & \multirow[t]{2}{*}{ QG } \\
\hline & & CsA dose & $\mathrm{T}$ & & $\mathrm{O} 1$ & $\mathrm{O} 2$ & $\mathrm{O} 3$ & $\mathrm{O} 4$ & & \\
\hline Jo [20] & HK-2 (H) & $0.5-10 \mu \mathrm{g} / \mathrm{ml}$ & $24 \mathrm{~h}$ & $\sqrt{ }$ & $\begin{array}{l}\text { Fas Fas-L } \\
\text { FADD } \\
\text { PARP }\end{array}$ & - & - & - & $\sqrt{ }$ & B \\
\hline Healy [9] & LLC-PK1 (P) & $0.42-84 \mu \mathrm{M}$ & $24 \mathrm{~h}$ & $\sqrt{ }$ & Fas & - & - & - & $\sqrt{ }$ & B \\
\hline Kim [28] & LLC-PK1 (P) & $1-100 \mathrm{ng} / \mathrm{ml}$ & $24 \mathrm{~h}$ & $\sqrt{ }$ & Fas & - & - & - & & B \\
\hline Cheng [24] & $\operatorname{MDCK}(\mathrm{C})$ & $20 \mu \mathrm{M}, 30 \mu \mathrm{M}$ & $24 \mathrm{~h}$ & J & - & Bcl-2 & - & $\begin{array}{l}\text { caspase- } 1,-2,-4 \\
-8,-9,-10,-3\end{array}$ & j & B \\
\hline Ortiz [27] & MCT (M) & $0.1-15 \mu \mathrm{g} / \mathrm{ml}$ & $24-72 \mathrm{~h}$ & $\sqrt{ }$ & - & - & - & caspase- $8,-9,-3$ & $\sqrt{ }$ & B \\
\hline Justo [25] & MCT (M) & $0.25-2 \mathrm{ng} / \mathrm{ml}$ & $12 \mathrm{~h}$ & $\sqrt{ }$ & Fas & - & Cyt-c, Bax & caspase- $2,-3,-9$ & $\sqrt{ }$ & B \\
\hline Han [29] & RMCs (R) & $0.1-40 \mu \mathrm{M}$ & $24 \mathrm{~h}$ & $\sqrt{ }$ & PARP & Bcl-2 & Bax & caspase- $3,-6$ & $\sqrt{ }$ & B \\
\hline
\end{tabular}

P: Proximal tubule epithelial cells (human, pig, canine, mice), rat mesangial cell (RMCs); I: CsA (different doses); T: co-cultured times; C: normal media; O: O1: Fas, Fas-L, FADD and PARP ( $\uparrow)$; O2: anti-apoptotic factors ( $\downarrow$ ); O3: pro-apoptotic factors ( $\uparrow)$; O4: cas-

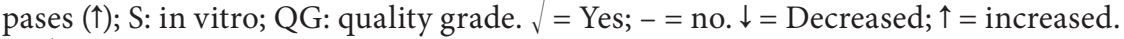

${ }^{1}$ Citation of included articles; different shading shows PICOS.

Fig. 2. Mechanisms of renal cell apoptosis induced by CsA.

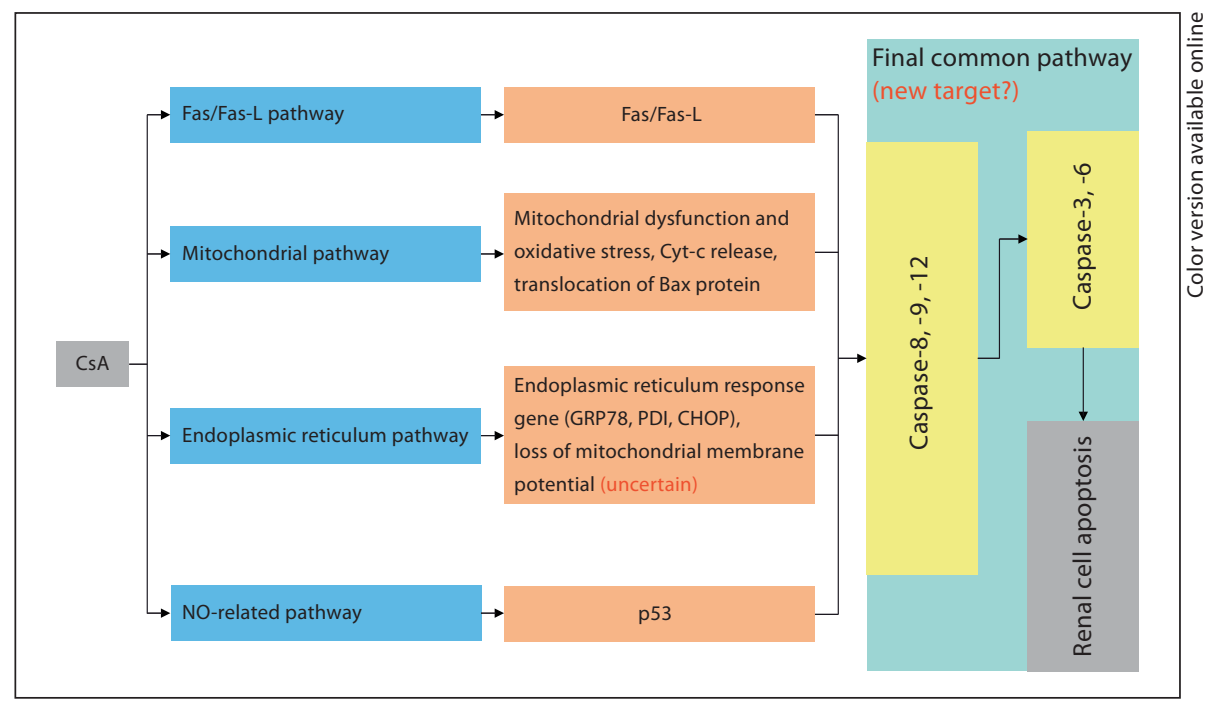

CsA $0.1-1 \mu \mathrm{g} / \mathrm{ml}$ could induce the human cell apoptosis (HK-2s, HECs and human mesangial cells) after about $24 \mathrm{~h}$ in vitro. There was a big difference of the concentration and co-culture time which CsA induced in renal cell apoptosis in other animal cell strains.

\section{Mechanisms of CsA-Induced Renal Cell Apoptosis in} vitro

Twenty-two experiments from 19 articles about the mechanisms of renal cell apoptosis induced by CsA are listed in tables $2-5$. There were four apoptotic pathways, namely Fas/Fas-L, mitochondrial, endoplasmic reticulum (ER), and NO-related pathway. They synergistically mediated cell apoptosis.

\section{Fas/Fas-L Pathway}

All 7 studies were included and their quality as score A shown in table 2. CsA induced cell apoptosis in a timeand dose-dependent manner when co-cultured with renal tubular epithelium of human/pigs/canine and mice for $24 \mathrm{~h}$. It upregulated expression of Fas and Fas-L in 4 studies, increased the FADD and cleavage product of 
Table 3. Mitochondrial apoptotic pathways

\begin{tabular}{|c|c|c|c|c|c|c|c|c|c|c|c|c|}
\hline \multirow{2}{*}{$\begin{array}{l}\text { Reference } \\
\text { (first author) }^{1}\end{array}$} & \multirow{2}{*}{$\begin{array}{l}\mathrm{P} \\
\text { cells/species }\end{array}$} & \multicolumn{2}{|l|}{ I } & \multirow[t]{2}{*}{$\mathrm{C}$} & \multicolumn{6}{|l|}{$\mathrm{O}$} & \multirow[t]{2}{*}{ S } & \multirow[t]{2}{*}{ QG } \\
\hline & & CsA & $\mathrm{T}$ & & $\mathrm{O} 1$ & $\mathrm{O} 2$ & $\mathrm{O} 3$ & O4 & O5 & O6 & & \\
\hline De Hornedo [10] & LLC-PK1 (pig) & $1 \mu \mathrm{M}$ & $24 \mathrm{~h}$ & $\sqrt{ }$ & $\sqrt{ }$ & $\sqrt{ }$ & NADP(H) GSH & - & - & - & $\sqrt{ }$ & B \\
\hline De Arriba [30] & LLC-PK1 (pig) & $0.1-10 \mu \mathrm{M}$ & $12-48 \mathrm{~h}$ & $\sqrt{ }$ & $\sqrt{ }$ & $\sqrt{ }$ & - & - & Cyt & caspase- 6 & $\sqrt{ }$ & B \\
\hline Jeon $[23]$ & MDCK (canine) & $10 \mu \mathrm{M}, 30 \mu \mathrm{M}$ & $24-48 \mathrm{~h}$ & $\sqrt{ }$ & V & $\sqrt{ }$ & catalase & Bcl-xL & Cyt & - & $\checkmark$ & B \\
\hline Justo [25] & MCT (mice) & $1-20 \mu \mathrm{g} / \mathrm{ml}$ & $12 \mathrm{~h}$ & $\checkmark$ & j & - & - & - & Cyt & $\begin{array}{l}\text { caspase }-2,-3 \text {, } \\
-9\end{array}$ & $\sqrt{ }$ & B \\
\hline Sarro [31] & РCT3 (mice) & $1-50 \mu \mathrm{g} / \mathrm{ml}$ & $0-60 \mathrm{~d}$ & $\sqrt{ }$ & - & - & - & - & - & - & $\checkmark$ & B \\
\hline Fornoni [32] & GEC (M) & $0.1-1 \mu \mathrm{g} / \mathrm{ml}$ & $1-48 \mathrm{~h}$ & $\sqrt{ }$ & - & - & - & Bcl-xL & - & - & $\sqrt{ }$ & B \\
\hline Cheng [24] & MDCK (C) & $20 \mu \mathrm{M}, 30 \mu \mathrm{M}$ & $24 \mathrm{~h}$ & $\sqrt{ }$ & - & - & - & Bcl-2 & - & caspase $-9,-3$ & $\checkmark$ & B \\
\hline Ortiz [27] & $\operatorname{MCT}(\mathrm{M})$ & $0.1-15 \mu \mathrm{g} / \mathrm{ml}$ & $24-72 \mathrm{~h}$ & $\sqrt{ }$ & - & - & - & - & - & caspase $-9,-3$ & $\checkmark$ & B \\
\hline Longoni [33] & HUVEC (H) & $200 \mu \mathrm{M}$ & $21 \mathrm{~h}$ & J & - & - & - & Bcl-2 & - & - & J & B \\
\hline
\end{tabular}

P: Proximal tubule epithelial cells (pig, canine and mice), vascular endothelial cells (human); I: CsA (different doses); T: co-cultured times; C: normal media; O: O1: mitochondrial dysfunction such as: permeability transition pores (opened), mitochondrial membrane potential ( $\downarrow$ ), cardiolipin content ( $\downarrow$ ), O2: superoxide anion ( $\uparrow)$, reactive oxygen species (ROS) ( $\uparrow)$; O3: antioxidative factors ( $\downarrow$ ); O4: anti-apoptotic factors (decreased); O5: pro-apoptotic factors $(\uparrow)$; O6: caspases $(\uparrow)$; S: in vitro; QG: quality grade. $\sqrt{ }=$ Yes; $-=$ no. $\downarrow=$ Decreased; $\uparrow=$ increased. GEC = Glomerular epithelial cells.

${ }^{1}$ Citation of included articles; different shading shows PICOS.

PARP in 2 studies, downregulated anti-apoptotic factors (Bcl-2 and $\mathrm{Bcl}-\mathrm{xL}$ ) with the cytochrome c release to cytosol and the translocation of Bax to the mitochondria, which led to the imbalance of $\mathrm{Bcl} / \mathrm{Bax}$ in 3 studies. The activity of caspases (caspase-2, $-3,-4,-7,-8,-9$ and -10 ) in co-cultured cells was also increased in 4 studies. Co-cultured with rat mesangial cells, CsA increased the cleavage product of PARP, downregulated the anti-apoptotic protein (Bcl-2) with the translocation of Bax to the mitochondria. The activity of the apoptosis enzymes (caspase-3 and -6) was increased in CsA-treated rat mesangial cells.

\section{Mitochondrial Pathway}

All 9 studies were included and their quality as score A shown in table 3. Different dosages of CsA significantly induced cell apoptosis when co-cultured with renal tubular epithelial cells of pig/canine and mice. CsA increased ROS in a dose-dependent manner. It induced mitochondrial dysfunction and oxidative stress in cocultured cells in 4 studies. It injured the antioxidant defense system, of which the NADPH and catalase were dramatically decreased in 2 studies. It caused Bax migration to mitochondria and also released cy tochrome c into cytosol in 3 studies. It downregulated anti-apoptotic proteins (Bcl-2 and Bcl-xL) in 4 studies and increased the activity of caspase-2, $-3,-6$, and -9 in 4 studies.
Endoplasmic Reticulum Pathway

Studies and their quality as score A were included and are shown in table 4 . CsA increased the expression of various genes mediating cell death during ER stress, e.g. GRP78, CHOP and HERP mRNA expression early, when co-cultured with human renal tubular epithelial cells. The activity of caspase- 3 and -7 was also increased in PTEC cells treated with CsA.

\section{Nitric Oxide-Related Pathway}

All 4 studies were included and their quality as score A shown in table 5. CsA could increase the nitric oxide (NO) in culture, when co-cultured with HK-2. When cocultured with human mesangial cells, HK-2, HUVECs, or ECs within 12-24 h, CsA significantly increased the protein expression of inducible nitric oxide synthase (iNOS) and p53 and the iNOS activity in all cell lines. When co-cultured with rat mesangial cells or murine endothelial cells, CsA could upregulate p53 and increase the activity of caspase- 3 and -6 .

\section{Discussion}

The molecular mechanisms by which cyclosporine induced chronic nephrotoxicity remain poorly understood. To reveal the mechanisms of renal cell apoptosis induced by CsA and provide new ideas for prevention, intervention and further studies of CRD, we systemati- 
Table 4. Endoplasmic reticulum pathway

\begin{tabular}{|c|c|c|c|c|c|c|c|c|c|}
\hline \multirow{2}{*}{$\begin{array}{l}\text { Reference } \\
\text { (first author) }^{1}\end{array}$} & \multirow{2}{*}{$\begin{array}{l}\mathrm{P} \\
\text { cells/species }\end{array}$} & \multicolumn{2}{|l|}{ I } & \multirow[t]{2}{*}{$\mathrm{C}$} & \multicolumn{3}{|l|}{$\mathrm{O}$} & \multirow[t]{2}{*}{$S$} & \multirow[t]{2}{*}{ QG } \\
\hline & & $\mathrm{CsA}$ & $\mathrm{T}$ & & $\mathrm{O} 1$ & $\mathrm{O} 2$ & $\mathrm{O} 3$ & & \\
\hline Pallet [34] & HRECs (human) & $6 \mu \mathrm{M}$ & $0-24 \mathrm{~h}$ & $\sqrt{ }$ & GRP78, PDI, CHOP, HERP & $\sqrt{ }$ & - & $\sqrt{ }$ & B \\
\hline Hortelano [35] & PTECs (pig) & $10 \mathrm{nM}$ & $24-72 \mathrm{~h}$ & $\sqrt{ }$ & - & - & caspase- $3,-7$ & $\sqrt{ }$ & B \\
\hline
\end{tabular}

P: Proximal tubule epithelial cells (human and pig); I: CsA (different doses); T: co-cultured times; C: normal media; O: O1: GRP78), C/EBP homology protein (CHOP) ( $\uparrow)$; O2: ER cisternae dilatations ( $\uparrow)$; O3: caspases ( $\uparrow)$; S: in vitro; QG: quality grade. $\sqrt{ }=$ Yes; $-=$ no. $\uparrow=$ Increased. HRECs $=$ Human renal tubular cells.

${ }^{1}$ Citation of included articles; different shading shows PICOS.

Table 5. NO-related pathway

\begin{tabular}{|c|c|c|c|c|c|c|c|c|c|c|}
\hline \multirow{2}{*}{$\begin{array}{l}\text { Reference } \\
\text { (first author) }^{1}\end{array}$} & \multirow{2}{*}{$\begin{array}{l}\mathrm{P} \\
\text { cells/species }\end{array}$} & \multicolumn{2}{|l|}{ I } & \multirow[t]{2}{*}{$\mathrm{C}$} & \multicolumn{4}{|l|}{$\mathrm{O}$} & \multirow[t]{2}{*}{ S } & \multirow[t]{2}{*}{ QG } \\
\hline & & CsA & $\mathrm{T}$ & & $\overline{\mathrm{O} 1 \uparrow}$ & $\mathrm{O} 2 \uparrow$ & $\mathrm{O} 3 \uparrow$ & $\mathrm{O} 4 \uparrow$ & & \\
\hline Esposito [17] & HEC, HK-2 (human) & $0.05-0.8 \mu \mathrm{g} / \mathrm{ml}$ & $24 \mathrm{~h}$ & $\sqrt{ }$ & $\mathrm{NO}$ & - & - & $\sqrt{ }$ & $\sqrt{ }$ & B \\
\hline Amore [18] & cells ${ }^{2}$ (human) & $0.1-1 \mu \mathrm{g} / \mathrm{ml}$ & $4-24 \mathrm{~h}$ & $\sqrt{ }$ & iNOS & P53 & - & $\sqrt{ }$ & $\sqrt{ }$ & B \\
\hline Conti [26] & $\mathrm{EC}$ (mice) & $0.25-2 \mu \mathrm{g} / \mathrm{ml}$ & $12 \mathrm{~h}$ & $\sqrt{ }$ & - & P53 & - & $\checkmark$ & $\sqrt{ }$ & B \\
\hline Han [29] & RMCs (rat) & $0.1-40 \mu \mathrm{M}$ & $24 \mathrm{~h}$ & $\sqrt{ }$ & - & P53 & caspase- $3,-6$ & $\sqrt{ }$ & $\sqrt{ }$ & B \\
\hline
\end{tabular}

P: Proximal tubule epithelial cells (human), RMCs and vascular endothelial cells (mice); I: CsA (different doses); T: co-cultured

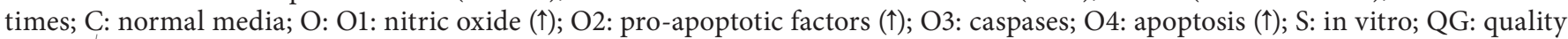
grade. $\sqrt{ }=$ Yes; $-=$ no. $\uparrow=$ Increased.

${ }^{1}$ Citation of included articles; different shading shows PICOS.

${ }^{2}$ Human mesangial cells, human tubular cells, human umbilical vein endothelial cells, or murine endothelial cells.

cally evaluated the in vitro studies about its mechanisms.

Nephrotoxicity is the major problem in the use of CsA. Our SR results demonstrated that CsA $0.1-1 \mu \mathrm{g} / \mathrm{ml}$ could induce human cell apoptosis (HK-2s, HECs and human mesangial cells) after about $24 \mathrm{~h}$ in vitro. CsA induced renal cell apoptosis in other animal cell strains, but there was a big difference of its concentration and co-culture time. This shows that it is dangerous when the serum CsA level is $>0.1 \mu \mathrm{g} / \mathrm{ml}$. Maintenance of CsA levels at the lower limits of the therapeutic range is desirable. There are more differences of serum CsA levels in different reports. Tan [36] reported that the optimal C2 (2 h peak concentration) target level of Chinese renal transplantation recipients was $1,250-1,500 \mathrm{ng} / \mathrm{ml}$ for the first 3 months post-transplantation. Wada et al. [37] reported that mean $\mathrm{C} 2$ values $>1,000 \mathrm{ng} / \mathrm{ml}$ were obtained in patients with no rejection at 1 and 12 months after transplantation in Japanese heart transplant patients. However, renal impairment may occur. Belitsky et al. [38] recommended that optimal C2 target levels were $1,700 \mathrm{ng} / \mathrm{ml}$ at $0-6$ months and $1,200 \mathrm{ng} / \mathrm{ml}$ at $6-12$ months in kidney transplant patients. In all, serum CsA levels are $>0.1 \mu \mathrm{g} / \mathrm{ml}$. Many studies confirmed that long-term use of CsA after renal transplantation could induce CCN [3-8]. Therefore, we think that CsA-induced renal cell apoptosis might be one of the primary causes in CRD. Its detailed mechanism becomes even more important for preventing CRD.

To reveal the mechanisms of renal cell apoptosis induced by CsA in vitro, we systematically analyzed all the relevant articles and collected 22 experiments about the mechanisms of renal cell apoptosis induced by CsA. Their apoptotic mechanisms are complex. At least four apoptotic pathways mediate renal cell apoptosis in vitro including the Fas/Fas-L, mitochondrial, ER and NO-related apoptotic pathway and synergistically mediated cell apoptosis (fig. 2).

Our SR results showed that CsA could significantly increase the Fas/Fas-L, FADD and PARP, induce mitochondrial dysfunction and oxidative stress and injure the 
antioxidant defense system. It also caused Bax migration to the mitochondria, released cytochrome $\mathrm{c}$ into cytosol, downregulated anti-apoptotic proteins ( $\mathrm{Bcl}-2$ and $\mathrm{Bcl}-$ $\mathrm{xL}$ ) and increased the activity of caspase- $2,-3,-4,-7,-8$, -9 and -10 . They finally activated caspase- 9 and -3 which mediate cell apoptosis [39-42]. All show that CsA can induce renal cell apoptosis through the Fas/Fas-L pathway and mitochondrial pathway with sufficient evidence.

ER stress is an adaptive response to many external stimuli such as oxidative stress, or exposure to many chemicals [43-46]. The ER stress markers could present important roles in cell apoptosis such as BIP, GRP78, CHOP, HERP, etc. The ER stress markers BIP/GRP78 were increased in CsA-treated renal allograft of kidney transplant recipients [47]. Our SR results showed that CsA could significantly increase the GRP78, CHOP and HERP mRNA early expression and activate caspase-3 and -7 when co-cultured with renal cells for 24-72 h. Gupta et al. [48] confirmed that apoptotic factors (caspase- 9 and -2 , Bcl-2) and loss of mitochondrial membrane potential showed important roles in ER stress-induced apoptosis [48]. However, they found that CsA could attenuate the loss of mitochondrial transmembrane potential (DeltaPsim) induced by ER stress. In another study, Bian et al. [49] found that caspase-4 was dually involved in inflammatory and ER stress-induced apoptotic responses in human retinal pigment epithelial cells. Therefore, all the evidence has shown that CsA might induce renal cell apoptosis through the ER pathway in vitro. Therefore, whether CsA induces renal cell apoptosis by the ER pathway needs to be confirmed by further studies.

$\mathrm{NO}$ is an important messenger molecule involved in both beneficial and harmful processes within the mammalian body [50]. Our SR results showed that CsA could induce apoptosis of various renal cell lines by enhancing NO synthesis, and this effect was mediated by the induction of iNOS via p53 and the activation of caspase- 3 and $-6[18,29,51]$. Finally, these might contribute to the acellular fibrosis characteristic of CCN. NO and the expression of endothelial (eNOS) and inducible (iNOS) isoforms of NOS were recognized as important mediators of physiological and pathological processes of renal injuries such as renal ischemia/reperfusion [52], partial or complete unilateral ureteral obstruction [53], chronic renal disease [54] and hydronephrosis [55], etc. NO and iNOS could contribute to renal injury through apoptosis of tubular epithelial cells [56]. Activation of caspase-8 plays a central role in NO-induced apoptosis [56]. Therefore, we think that NO-related pathway is an important pathway of CsA-induced renal cell apoptosis.
The four pathways shown in this study might provide four points for interventions. For example, can one intervention inhibit apoptosis by blocking four pathways simultaneously? Four pathways simultaneously are hardly blocked by one intervention. Or do they have a common pathway? All the above evidence shows that CsA can activate caspases through four pathways in co-cultured cells and finally mediate cell apoptosis, then these caspases might be the ultimate intersection of these apoptotic pathways and their final common pathway. If so, it will be the new target for intervention in CNN.

This study demonstrated that at least four pathways mediated CsA-induced renal cell apoptosis with different cells species in vitro. Caspases might be their final common pathway in vitro. They might all provide potential point for interventions, but these need to be confirmed in vivo. We will report the mechanisms of renal cell apoptosis induced by CsA in vivo in another SR.

\section{Appendix}

I. Search terms: Nephrotoxicity, Cyclosporine A, CsA, CyA, Cyclosporine, Renal tubular epithelial cell, Renal cells and Apoptosis.

II. Search strategy; First: (Nephrotoxicity and (Cyclosporine A or CsA or CyA or Cyclosporine)) and Apoptosis. Second: Cyclosporine A or CsA or CyA or Cyclosporine) and (Renal tubular epithelial cell or Renal cells) and Apoptosis). Third: First or Second.

III. Search Members: Z. Xiao and C. Li.

IV. Databases and search time: Medline (1966 to July 2010), Embase (1974 to July 2010) and ISI (1986 to July 2010).

V. Research results: Medline $(\mathrm{n}=99)$, Embase $(\mathrm{n}=171)$ and ISI $(\mathrm{n}=184)$.

\section{Acknowledgment}

This work was funded by grants from the National 973 Project Foundation of China, No. 2009CB522401.

\section{Disclosure Statement}

The authors have no conflicts of interest to declare. 


\section{References}

1 Ponticelli C: Cyclosporine: from renal transplantation to autoimmune diseases. Ann N Y Acad Sci 2005; 1051:551-558.

- 2 Gisslinger $\mathrm{H}$, Burghuber OC, Stacher G, Schwarz W, Punzengruber C, Graninger W, Luger TA, Wolff K, Smolen JS: Efficacy of cyclosporin A in systemic sclerosis. Clin Exp Rheumatol 1991;9:383-390.

-3 Montagnino G, Banfi G, Campise MR, Passerini P, Aroldi A, Cesana BM, Ponticelli C: Impact of chronic allograft nephropathy and subsequent modifications of immunosuppressive therapy on late graft outcomes in renal transplantation. Nephrol Dial Transplant 2004;19:2622-2629.

-4 Magnasco A, Rossi A, Catarsi P, Gusmano R, Ginevri F, Perfumo F, Ghiggeri GM: Cyclosporin and organ specific toxicity: clinical aspects, pharmacogenetics and perspectives. Curr Clin Pharmacol 2008;3:166-173.

-5 Benigni A, Bruzzi I, Mister M, Azzollini N, Gaspari F, Perico N, Gotti E, Bertani T, Remuzzi G: Nature and mediators of renal lesions in kidney transplant patients given cyclosporine for more than one year. Kidney Int 1999;55:674-685.

- 6 Takeda A, Uchida K, Haba T, Tominaga Y, Katayama A, Yoshida A, Oikawa T, Morozu$\mathrm{mi} \mathrm{K}$ : Chronic cyclosporin nephropathy: long-term effects of cyclosporin on renal allografts. Clin Transplant 2001;15(suppl 5):22-29.

7 Seron D, Moreso F, Grinyo JM: Prevention and management of late renal allograft dysfunction. J Nephrol 2001;14:71-79.

-8 Marcen R, Pascual J, Teruel JL, Villafruela JJ, Rivera ME, Mampaso F, Burgos FJ, Ortuno $\mathrm{J}$ : Outcome of cadaveric renal transplant patients treated for 10 years with cyclosporine: Is chronic allograft nephropathy the major cause of late graft loss? Transplantation 2001; 72:57-62.

9 Healy E, Dempsey M, Lally C, Ryan MP: Apoptosis and necrosis mechanisms of cell death induced by cyclosporine $\mathrm{A}$ in a renal proximal tubular cell line. Kidney Int 1998; 54:1955-1966.

-10 De Hornedo JP, De Arriba G, Calvino M, Benito S, Parra T: Cyclosporin A causes oxidative stress and mitochondrial dysfunction in renal tubular cells. Nefrologia 2007;27: 565-573.

-11 Del Moral RG, Andujar M, Ramirez C, Gomez-Morales M, Masseroli M, Aguilar M, Olmo A, Arrebola F, Guillen M, Garcia-Chicano MJ, Nogales FF, O’Valle F: Chronic cyclosporin A nephrotoxicity, P-glycoprotein overexpression, and relationships with intrarenal angiotensin ii deposits. Am J Pathol 1997;151:1705-1714.
12 Pichler RH, Franceschini N, Young BA, Hugo C, Andoh TF, Burdmann EA, Shankland SJ, Alpers CE, Bennett WM, Couser WG, et al: Pathogenesis of cyclosporine nephropathy: roles of angiotensin ii and osteopontin. J Am Soc Nephrol 1995;6:1186-1196.

13 Shihab FS, Bennett WM, Tanner AM, Andoh TF: Angiotensin ii blockade decreases TGF$\beta_{1}$ and matrix proteins in cyclosporine nephropathy. Kidney Int 1997;52:660-673.

14 Shihab FS, Andoh TF, Tanner AM, Noble NA, Border WA, Franceschini N, Bennett WM: Role of transforming growth factor- $\beta_{1}$ in experimental chronic cyclosporine nephropathy. Kidney Int 1996;49:1141-1151.

15 Shihab FS, Andoh TF, Tanner AM, Bennett WM: Sodium depletion enhances fibrosis and the expression of TGF- $\beta_{1}$ and matrix proteins in experimental chronic cyclosporine nephropathy. Am J Kidney Dis 1997;30: 71-81.

16 Center SDM: EBM Evidence Pyramid (http:// librarydownstateedu/ebmdos $/ 2100 \mathrm{htm}$ 2001).

17 Esposito C, Fornoni A, Cornacchia F, Bellotti N, Fasoli G, Foschi A, Mazzucchelli I, Mazzullo T, Semeraro L, Dal Canton A: Cyclosporine induces different responses in human epithelial, endothelial and fibroblast cell cultures. Kidney Int 2000;58:123-130.

18 Amore A, Emancipator SN, Cirina P, Conti G, Ricotti E, Bagheri N, Coppo R: Nitric oxide mediates cyclosporine-induced apoptosis in cultured renal cells. Kidney Int 2000; 57:1549-1559.

19 Daly PJ, Docherty NG, Healy DA, McGuire BB, Fitzpatrick JM, Watson RW: The single insult of hypoxic preconditioning induces an anti-apoptotic response in human proximal tubular cells, in vitro, across cold storage. BJU Int 2009;103:254-259.

20 Jo SK, Lee SY, Han SY, Cha DR, Cho WY, Kim HK, Won NH: Alpha-melanocyte stimulating hormone decreases cyclosporine A induced apoptosis in cultured human proximal tubular cells. J Korean Med Sci 2001;16: 603-609.

21 De Arriba G, de Hornedo JP, Rubio SR, Fernandez MC, Martinez SB, Camarero MM, Cid TP: Vitamin E protects against the mitochondrial damage caused by cyclosporin A in LLC-PK1 cells. Toxicol Appl Pharmacol 2009;239:241-250.

22 Perez M, Castilla M, Torres AM, Lazaro JA, Sarmiento E, Tejedor A: Inhibition of brush border dipeptidase with cilastatin reduces toxic accumulation of cyclosporin A in kidney proximal tubule epithelial cells. Nephrol Dial Transplant 2004;19:2445-2455.

23 Jeon SH, Piao YJ, Choi KJ, Hong F, Baek HW, Kang I, Ha J, Kim SS, Chang SG: Prednisolone suppresses cyclosporin A induced apoptosis but not cell cycle arrest in MDCK cells. Arch Biochem Biophys 2005;435:382-392.
24 Cheng $\mathrm{CH}$, Hsieh CL, Shu KH, Chen YL, Chen HC: Effect of calcium channel antagonist diltiazem and calcium ionophore A23187 on cyclosporine A-induced apoptosis of renal tubular cells. FEBS Lett 2002;516: 191-196.

25 Justo P, Lorz C, Sanz A, Egido J, Ortiz A: Intracellular mechanisms of cyclosporin A-induced tubular cell apoptosis. J Am Soc Nephrol 2003; 14:3072-3080.

26 Conti G, Amore A, Cirina P, Gianoglio B, Peruzzi L, Coppo R: Cyclosporin induces apoptosis of renal cells by enhancing nitric oxide synthesis modulating effect of angiotensin ii inhibitors. Transplant Proc 2001;33:276-277.

27 Ortiz A, Lorz C, Catalan M, Coca S, Egido J: Cyclosporine $\mathrm{A}$ induces apoptosis in murine tubular epithelial cells: role of caspases. Kidney Int Suppl 1998;68:S25-S29.

28 Kim SI, Song HY, Hwang JH, Chong DL, Lee HY, Han DS, Moon JI, Kim YS, Park KI, Kim KS, Choi KH: Cyclosporine nephrotoxicity the mechanisms of cell injury by cyclosporine A in renal proximal tubular cells. Transplant Proc 2000;32:1621-1622.

29 Han SY, Chang EJ, Choi HJ, Kwak CS, Park SB, Kim HC, Mun KC: Apoptosis by cyclosporine in mesangial cells. Transplant Proc 2006;38:2244-2246.

-30 De Arriba G, de Hornedo JP, Rubio SR, Fernandez MC, Martinez SB, Camarero MM, Cid TP: Vitamin E protects against the mitochondrial damage caused by cyclosporin A in 1LC-PK1 cells. Toxicol Appl Pharmacol 2009;239:241-250

- 31 Sarro ET, Tornavaca O, Plana M, Meseguer A, Itarte E: Phosphoinositide 3-kinase inhibitors protect mouse kidney cells from cyclosporine-induced cell death. Kidney Int 2008; 73:77-85.

- 32 Fornoni A, Li H, Foschi A, Striker GE, Striker LJ: Hepatocyte growth factor but not insulin like growth factor I protects podocytes against cyclosporin A-induced apoptosis. Am J Pathol 2001;158:275-280.

33 Longoni B, Boschi E, Demontis GC, Ratto GM, Mosca F: Apoptosis and adaptive responses to oxidative stress in human endothelial cells exposed to cyclosporin A correlate with Bcl-2 expression levels. FASEB J 2001;15:731-740.

34 Pallet N, Bouvier N, Bendjallabah A, Rabant M, Flinois JP, Hertig A, Legendre C, Beaune $\mathrm{P}$, Thervet E, Anglicheau D: Cyclosporineinduced endoplasmic reticulum stress triggers tubular phenotypic changes and death. Am J Transplant 2008;8:2283-2296.

35 Hortelano S, Castilla M, Torres AM, Tejedor A, Bosca L: Potentiation by nitric oxide of cyclosporin A and FK506-induced apoptosis in renal proximal tubule cells. J Am Soc Nephrol 2000;11:2315-2323. 
36 Tan J: Neoral C2 monitoring in Chinese renal transplantation recipients. Chin J Urol 2003;24:172-174.

$\checkmark 37$ Wada K, Takada M, Ueda T, Ochi H, Morishita H, Hanatani A, Nakatani T: Pharmacokinetic study and limited sampling strategy of cyclosporine in Japanese heart transplant recipients. Circ J 2006;70:1307-1311.

>38 Belitsky P, Levy GA, Johnston A: Neoral absorption profiling: an evolution in effectiveness. Transplant Proc 2000;32:45S-52S.

-39 Saikumar P, Dong Z, Weinberg JM, Venkatachalam MA: Mechanisms of cell death in hypoxia/reoxygenation injury. Oncogene 1998;17:3341-3349.

40 Moley KH, Mueckler MM: Glucose transport and apoptosis. Apoptosis 2000;5:99105.

41 Boulikas T, Vougiouka M: Cisplatin and platinum drugs at the molecular level. Oncol Rep 2003;10:1663-1682.

42 Marchetti P, Mortier L, Beauvillain V, Formstecher P: Are mitochondria targets of anticancer drugs responsible for apoptosis? Ann Biol Clin (Paris) 2002;60:391-403.

43 Xu C, Bailly-Maitre B, Reed JC: Endoplasmic reticulum stress: cell life and death decisions. J Clin Invest 2005;115:2656-2664

44 Montie HL, Kayali F, Haezebrouck AJ, Rossi NF, Degracia DJ: Renal ischemia and reperfusion activates the eIF-2 $\alpha$ kinase perk. Biochim Biophys Acta 2005;1741:314-324.
45 Mori K: Tripartite management of unfolded proteins in the endoplasmic reticulum. Cell 2000;101:451-454.

46 Zhang K, Kaufman RJ: Signaling the unfolded protein response from the endoplasmic reticulum. J Biol Chem 2004;279:2593525938.

47 Pallet N, Rabant M, Xu-Dubois YC, Lecorre D, Mucchielli MH, Imbeaud S, Agier N, Hertig A, Thervet E, Legendre C, Beaune P, Anglicheau D: Response of human renal tubular cells to cyclosporine and sirolimus: a toxicogenomic study. Toxicol Appl Pharmacol 2008;229:184-196.

48 Gupta S, Cuffe L, Szegezdi E, Logue SE, Neary C, Healy S, Samali A: Mechanisms of ER stress-mediated mitochondrial membrane permeabilization. Int J Cell Biol 2010; 2010:170-215.

49 Bian ZM, Elner SG, Elner VM: Dual involvement of caspase- 4 in inflammatory and ER stress-induced apoptotic responses in human retinal pigment epithelial cells. Invest Ophthalmol Vis Sci 2009;50:6006-6014

50 Ray A, Chakraborti A, Gulati K: Current trends in nitric oxide research. Cell Mol Biol (Noisy-le-grand) 2007;53:3-14.

51 Conti G, Amore A, Cirina P, Gianoglio B, Peruzzi L, Coppo R: Cyclosporin induces apoptosis of renal cells by enhancing nitric oxide synthesis: modulating effect of angiotensin II inhibitors. Transplant Proc 2001;33:276277.
52 Vinas JL, Sola A, Genesca M, Alfaro V, Pi F, Hotter G: NO and NOS isoforms in the development of apoptosis in renal ischemia/reperfusion. Free Radic Biol Med 2006;40:9921003.

53 Yoo KH, Thornhill BA, Forbes MS, Chevalier RL: Inducible nitric oxide synthase modulates hydronephrosis following partial or complete unilateral ureteral obstruction in the neonatal mouse. Am J Physiol Renal Physiol 2010;298:F62-F71.

54 Nakayama T, Sato W, Kosugi T, Zhang L, Campbell-Thompson M, Yoshimura A, Croker BP, Johnson RJ, Nakagawa T: Endothelial injury due to ENOS deficiency accelerates the progression of chronic renal disease in the mouse. Am J Physiol Renal Physiol 2009; 296:F317-F327.

-55 Kipari T, Cailhier JF, Ferenbach D, Watson S, Houlberg K, Walbaum D, Clay S, Savill J, Hughes J: Nitric oxide is an important mediator of renal tubular epithelial cell death in vitro and in murine experimental hydronephrosis. Am J Pathol 2006;169:388-399.

56 Du C, Guan Q, Diao H, Yin Z, Jevnikar AM: Nitric oxide induces apoptosis in renal tubular epithelial cells through activation of caspase-8. Am J Physiol Renal Physiol 2006; 290:F1044-F1054. 